\title{
坊勢海水交換型防波堤ケーソンの 導水量の実機計測 \\ FIELD MEASUREMENT ON CONDUCTED WATER OF WATER-EXCHANGING BREAKWATER- CAISSON IN BOSE FISHING PORT
}

\author{
島田潔 $1 \cdot$ 吉村正 ${ }^{2} \cdot$ 杉本達彦 $3 \cdot$ 五十嵐和之 $4 \cdot$ 宮内勇児 $5 \cdot$ 大野邦彦 6 \\ Kiyoshi SHIMADA, Tadashi YOSHIMURA, Tatsuhiko SUGIMOTO, \\ Kazuyuki IGARASHI, Yuji MIYAUCHI and Kunihiko OHNO \\ 1工修 侏三井造船昭島研究所 事業統括部（テ 196-0012 東京都昭島市つつじヶ丘1-1-50） \\ 2 正会員 工修 三井造船(株) 鉄構·物流事業本部技術部（广 104-0045 東京都中央区築地5-6-4） \\ 3 三井造船侏 鉄構·物流事業本部技術部（ \\ 4(侏三井造船昭島研究所 事業統括部（テ196-0012 東京都昭島市つつじヶ丘1-1-50） \\ 5 兵庫県農林水産部農林水産局漁港課（ $\mathrm{T} 650-8567$ 兵庫県神戸市中央区下山手通5-10-1） \\ 6 家島町坊勢支所漁港係（テ672-0103 兵庫県飾磨郡家島町坊勢186番地）
}

\begin{abstract}
Field measurement was carried out for the breakwater caisson newly built in Bose fishing port with the purpose of confirming the capability of water exchange resulting from incident waves. Because Bose is situated in inland-sea area, incident waves are as small as $0.15 \mathrm{~m}$ in height, which are generated mainly by running ships. In spite of small waves net quantity of conducted water excluding water-current contribution is obtained as much as $5 \mathrm{~m}^{3}$ per one hour for $1 \mathrm{~m}$ caisson. Predicted values of conducted water based on the model experiment are roughly same as those of field measurement.
\end{abstract}

Key Words : water exchange, breakwater caisson, field measurement

\section{1.はじめに}

港内の水質環境の観点から，防波堤の海水交換機 能の重要性が認識されてきており, 著者らも防波堤 および護岸の海水交換機能に関する実験的研究を実 施してきた ${ }^{1) ~ 3)}$ 。中でもスリット付ケーソンは潮 位変化に上らず安定した導水量が確保できるため, 実際に設置されることが多い。

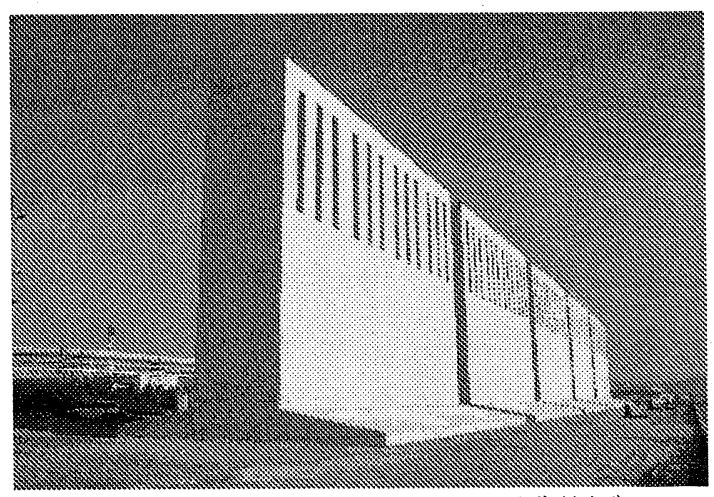

写真-1 スリット付ケーソン（港外側）
本研究では, 兵庫県家島町坊勢漁港に設置された 西 5 号防波堤ケーソン（写真-1）の導水量を実測し, その海水交換機能を検証するとともに, 水槽実験結 果との比較によって水槽実験の有効性を実証した. ケーソンの主要目は次の通りである。

$$
\begin{aligned}
& \text { ケーソン部 } \\
& \text { 幅： } 4.2 \mathrm{~m} \\
& \text { 高さ： } 15.45 \mathrm{~m} \\
& \text { 長さ： } 19.9 \mathrm{~m} \times 5 \text { 基 } \\
& \text { スリット : } 0.55 \mathrm{~m} \times 5.4 \mathrm{~m} \times 12 \text { 個（1基当たり） } \\
& \text { 導水口： } 0.6 \mathrm{~m} \phi \times 8 \text { 個（1基当たり） }
\end{aligned}
$$

\section{2. 現地計測}

(1) 計測期間

計測期間および時間は次の通りである.

計測期間：平成13年8月 29 日 9月 1 日

計測時間：午前 8 時〜午後 4 時に 20 分間の計測 を5回実施 


\section{(2) 計測方法}

ケーソンから港内側および港外側に $30 \mathrm{~m}$ 程度離れ た位置に圧力センサー式波高計を設置し，波高を計 測した. 今回使用した波高刑は吊下げ型の圧力セン サー式であり，短周期の波に適用できるものである. 短周期の波では水面擋乱の影響は鉛直方向に急激に 減衰するため圧力センサーには水面擋乱の影響は伝 わらない，一方，水面上のブイは水面波動と同じ上
下動を行うため，上下動に対応した静圧変化がセン サーに生じ，波高が圧力の形で計測されることにな る. 今回のように波周期が 3 秒程度の波では, 妥当 な計測精度が確保できることが，ブイ式波高計との 比較によって検証されている.

導水流速については, 導水口の出口付近 2 カ所に 電磁流速計を設置し計測を行った。波高計および流 速計の配置を図-1〜図-3に示す.

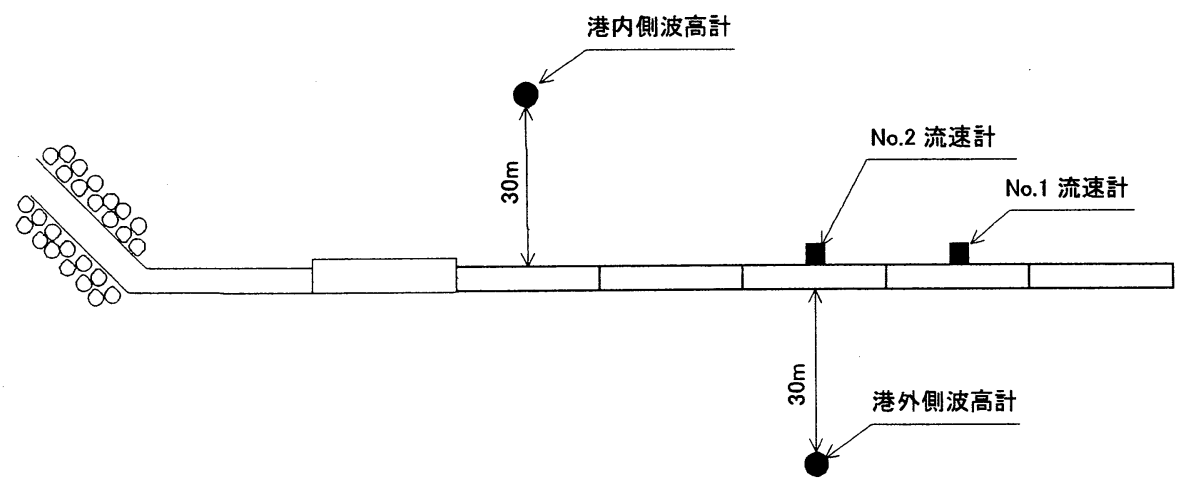

図-1 波高計および流速計の配置図（平面図）

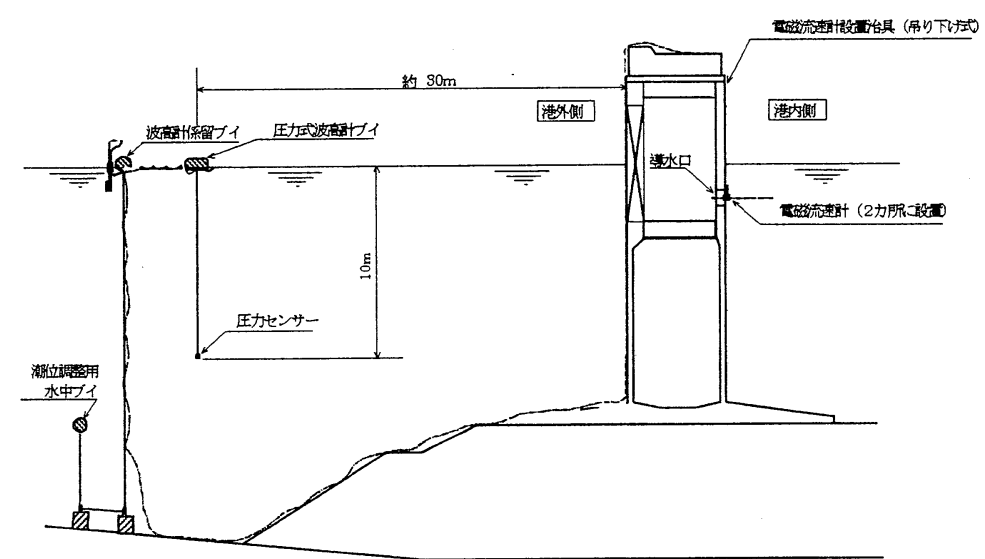

図-2 波高計および流速計の配置図（断面図）

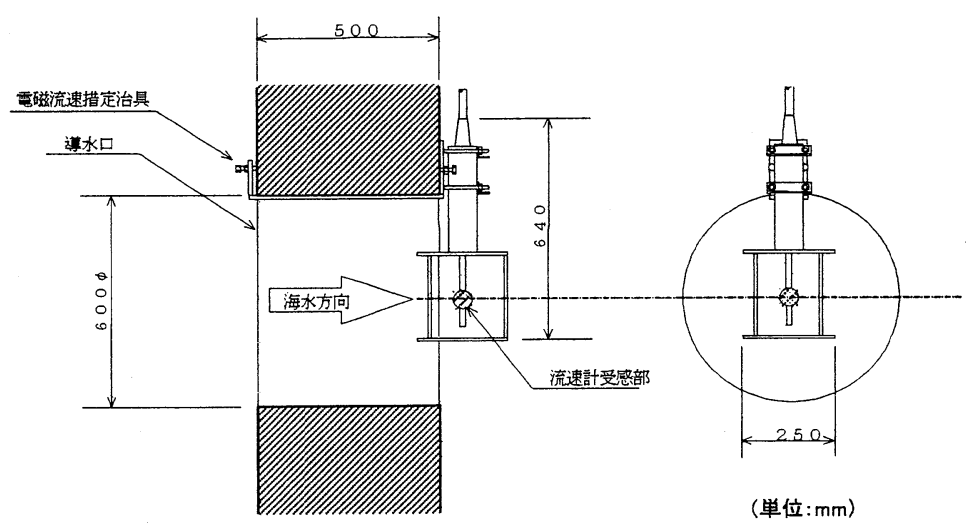

図-3＼cjkstart流速計の設置図（断面図詳細） 


\section{3. 計測結果および解析方法}

海水交換型ハイブリッドケーソンへの入射波およ び導水口における導水流速を，約 2 時間置きに20分 間に亘り同時計測した。 8月 30日 12時〜20分の計測 結果の一部を図-4に示す。図-4からわかるように波 高が大きい時間帯と比較的小さい時間帯が存在する. この波高が比較的小さい時間帯（図-4の例では 12.5 分〜14分）を，波高の影響がなく潮流による導水流 速が得られているものとみなし, その間の平均流速 Vcを求めた。波浪影響の他に潮流影響を含んだ導水 流速Voは，20分間の計測データの平均值として求め た。したがって，波浪による導水流速は

$$
\mathrm{V}_{\mathrm{w}}=\mathrm{V}_{\mathrm{o}}-\mathrm{V}_{\mathrm{c}}
$$

で求められることになる。

図-5に，4日間に亘る導水流速と水位の変化を示 す。なお， 2 基の流速計による結果はほぼ同じで あったため, 両者の平均值を示した. 導水流速の計 測值は最大で $0.1 \mathrm{~m} / \mathrm{s}$ 程度であるが，波高が小さいた め，潮流による流速が支配的であることがわかる。

図-6に波浪条件（有義波高／有義波周期）と波浪 による導水流速を示す。波浪による成分は高々 $0.03 \mathrm{~m} / \mathrm{s}$ 程度と小さい。このときの波浪は，有義波 高0. 1 0. $2 \mathrm{~m}$ 程度, 有義波周期 $2.5 \sim 3.5$ 秒程度であ り，航跡波が主体であった．以下、導水流速とは、 波浪による導水流速Vwを示すものとする。
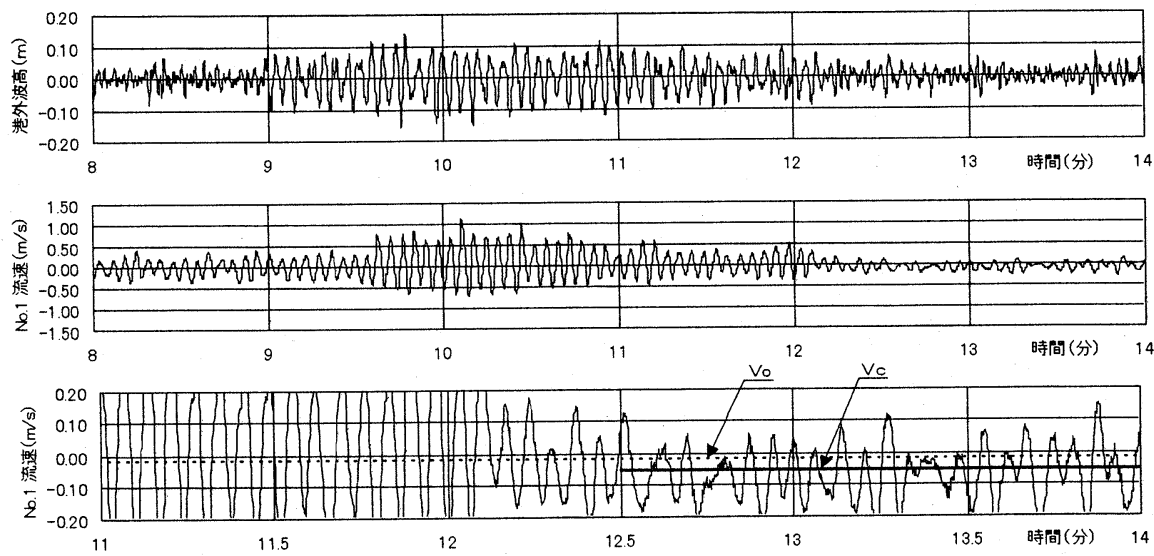

図-4＼cjkstart波高と流速の計測例 （8/30 12:00～12:20）

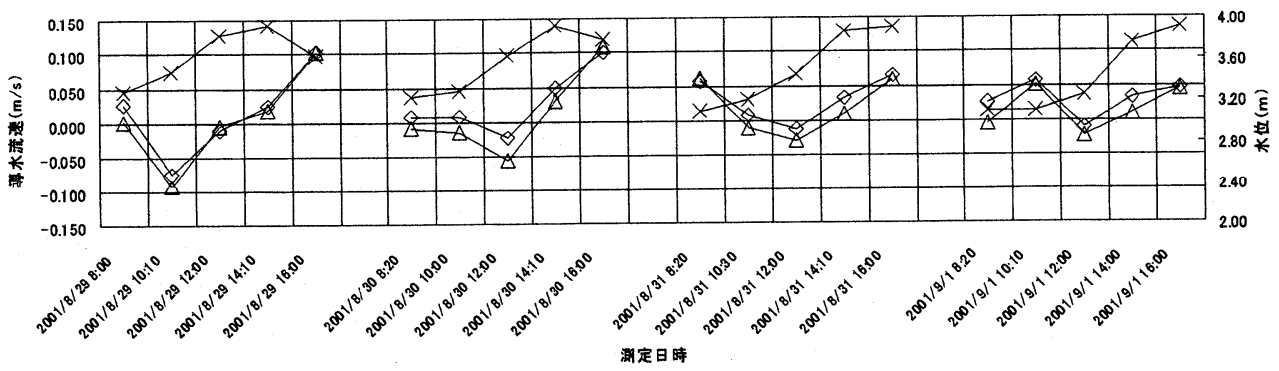

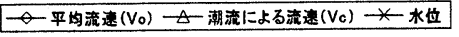

図-5 各計測日時の平均流速

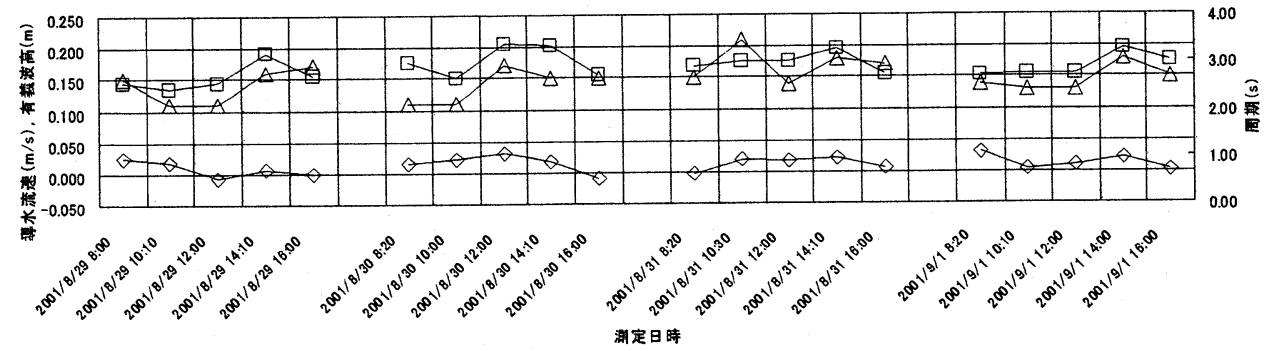

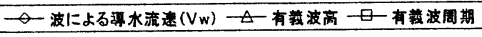

図-6 各計測日時の波による導水流速 


\section{4. 水槽試験との比較}

図-7, 図-8には導水流速および導水量の現地計測 結果を水槽実験 ${ }^{3)}$ から得られた推定值と比較して示 す.ここで, 導水流速の推定值は， $1 / 20$ 模型を用い て実施した波高 $0.3 \mathrm{~m}$, 波周期 3 秒に対する実験值に 波高修正係数（=計測有義波高 $/ 0.3 \mathrm{~m}$ ) を乗じて求
めた。 また，導水量は導水流速に導水口の面積をか けて求めた。

導水流速の推定值は $0.01 \mathrm{~m} / \mathrm{s}$ 程度となっている. 一方，現地計測結果はバラツキが大きいものの，推 定値とほぼ同程度の大きさとなっている. 導水量も 同様の結果であり，長さ $1 \mathrm{~m}$ ケーソンで 1 時間当た り約 $5 \mathrm{~m}^{3}$ が得られている。

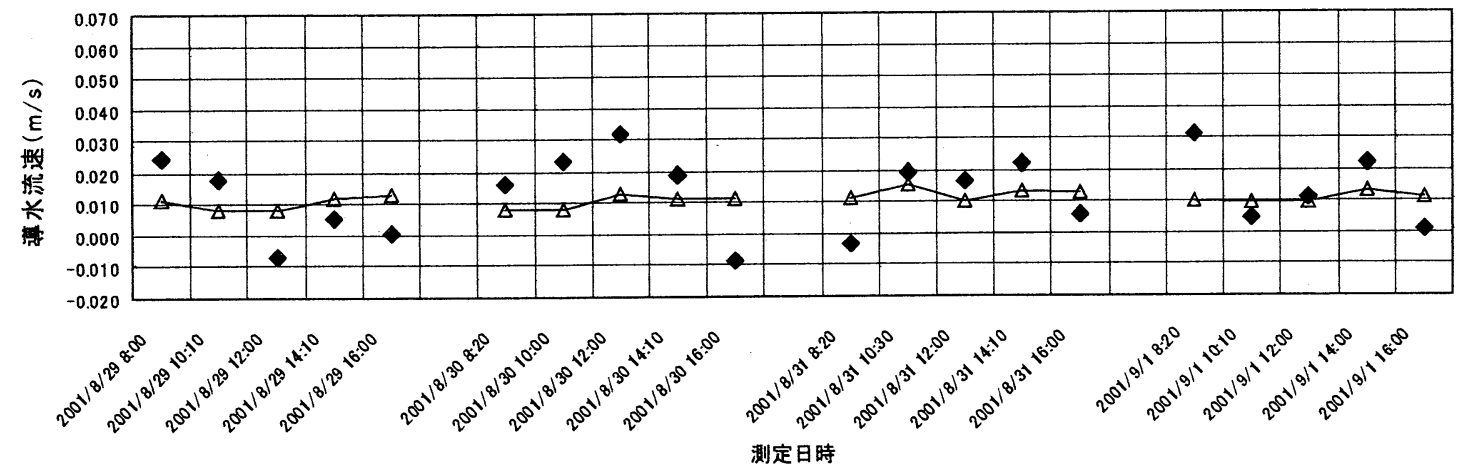

- 現地到湔結果 $\left(\mathrm{V}_{\mathrm{w}}\right) \triangle$ 椎定值

図-7導水流速の比較

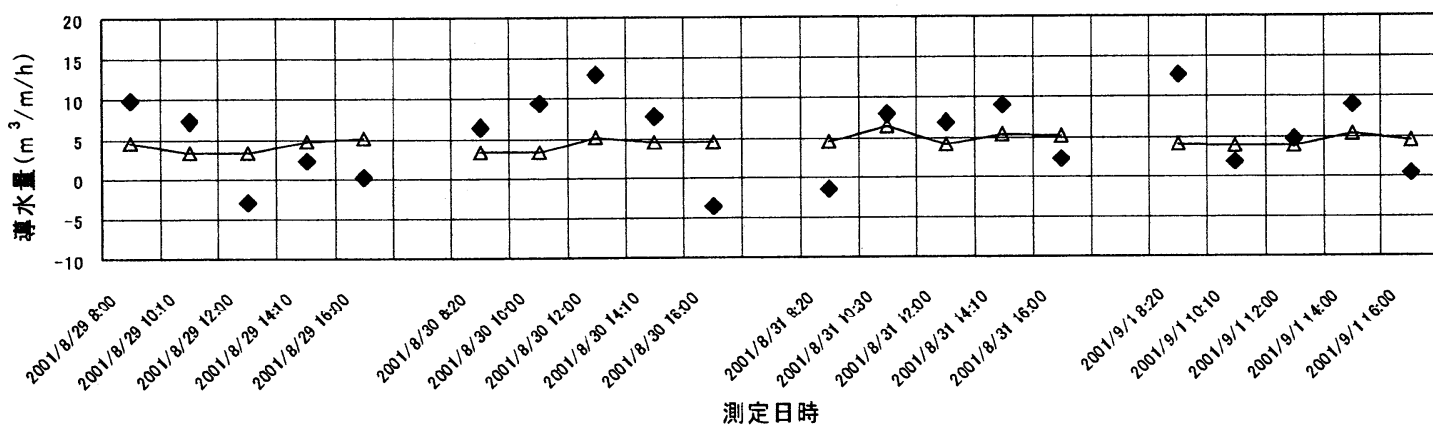

現地到润結果 $九$ 一推定值

図-8 単位長さにおける 1 時間当たりの導水量の比較

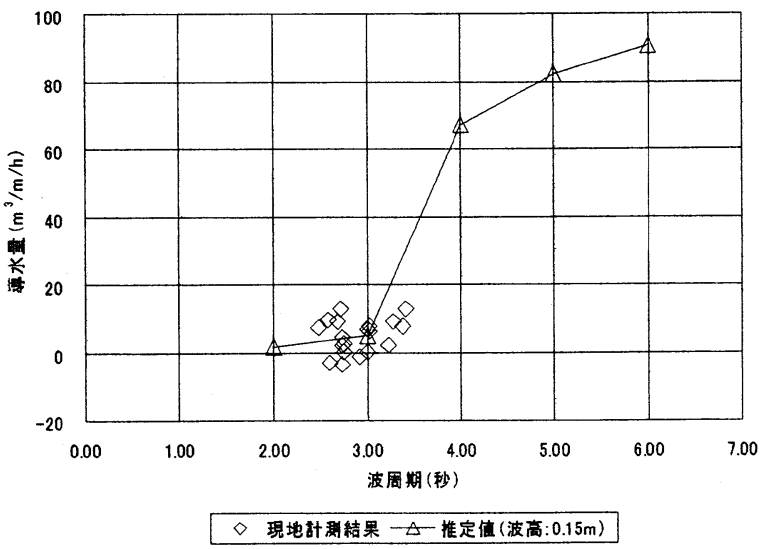

図-9 単位長さに対する 1 時間当たりの導水量
図-9は，横軸に波周期を取って導水量の現地計測 結果と水槽実験による推定值を比較したものである. 推定值は波高を0. $15 \mathrm{~m}$ と想定し，0.3mで実施した実 験值の $1 / 2$ とした。現地計測時の波高が小さく波周 期も短いため得られた導水量は少ないが，有意な導 水量が得られており，また，現地計測結果と水槽実 験による推定結果の対応もほぼ良好と考えられる. 


\section{5. おわりに}

現地計測時には波浪は航跡波が主体であり, 波高 も $0.15 \mathrm{~m}$ 程度の小波高であったが，ケーソン単位長 さ当たりで毎時約 $5 \mathrm{~m}^{3}$ の導水量が得られており, 本 ケーソンの海水交換能力が実証された.

現地計測では波浪は航跡波が主体であり，㛜密 には水槽実験と条件が異なるが，水槽実験結果から 推定した導水量と現地計測結果は，概水良好な定量 的関係を示しており，水槽実験による導水量推定が， 有効であることが確認された。

今後は, 設置海域の波浪条件に適合した海水交 換型ケーソン形状の最適化を行うとともに，海水交 換型ケーソンに要求される海水交換能力の定量化を 行っていくことが必要と考えられる.このとき, 潮
汐による海水交換の影響も考慮することが必要と思 われる。

\section{参考文献}

1）島田潔，ほか：衝立パネル式ケーソンの海 水交換特性に関する実験的研究，海洋開発 論文集，第 15 巻， 1999 .

2）島田潔，ほか：スリット付き海水交換型防 波堤および鉛直混合型護岸の開発，海洋開 発論文集，第 16 巻， 2000 .

3）島田潔，ほか：海水交換型ケーソンの導水 流制御機構, 海洋開発論文集, 第 17 巻, 2001. 